\title{
The Effectiveness of Current Approaches to Teaching Novel to University EFL Learners : Investigation \& Reflections
}

\author{
Ahmed Khalis Shalan \\ College of Languages, Nawroz University, Kurdistan Region-Iraq
}

\begin{abstract}
Taking the novel as a model of study, the plan of this study was of two dimensions. The first dimension was to make interviews with 6 teachers of English novel to the juniors and seniors, in 4 departments of English in 3 universities within Duhok Governorate Area. The interview form made use of Lazar's (2013) tri-assumed-alternative approaches model to teach literature; a language-based approach, literature as content approach, and literature for personal enrichment approach. The teachers of novel were asked to tell how far their approaches of teaching novel are identical with one of Lazar model's three approaches, as well as to fill in a questionnaire about their training to teach literature. The second dimension was to design a questionnaire to investigate the learners' reflections about their learning and study experience with the novel-teaching approaches used by their teachers. Finally, an analysis of the findings was made, which helped to develop certain conclusions which proved the hypotheses made by the research about the professionalism of the novel-teacher's approaches to teaching novel. In addition certain recommendations were made suggesting raising the sailing of the novel-teachers training in how to teach literature.
\end{abstract}

KEYWORDS : Literary Awareness, Literary Education, Literary Competence, Professionalism.

\section{INTRODUCTION}

Teaching literature in the EFL tertiary level's classroom always brings in the demand vital questions to be answered, such as :

- Is teaching literature like, for instance, teaching Grammar, or pronunciation, or reading comprehension, or communication, or conversation, or linguistics?

Controversially, exactly two opposite answers might be heard :

- Utterly, no! ...

or

- Definitely, yes!

The party of 'No' might view teaching literature as a really different matter from teaching the other subjects in a language classroom, because they believe that literature should be taught for itself not for any other sake. Meanwhile, the party of 'Yes', argue that since teaching literature is viewed as a linguisticallyculturally integral part of any EFL Curriculum, it could really bring the teaching of other EFL-subjects altogether in the language-classroom.

Academic Journal of Nawroz University

(AJNU) Volume 7, No 3 (2018).

Received 10 April 2018;

Regular research paper : Published 20 July 2018

Corresponding author's e-mail : a_kh_shalan@yahoo.com

Copyright (02018 Ahmed Khalis Shalan.

This is an open access article distributed under the

Creative Commons Attribution License.
However, another vital question is still to be posed :

- Is literature 'caught or taught'?

CAUGHT means that teaching literature has to do with the approach of teaching literature for its own right, and it also means it has to do, at first and above all, with the students' interaction with novel-reading as part of a certain culture.

Meanwhile, TAUGHT means that the approach of teaching literature must serve, as an instrumental tool, in the teaching of language, which eventually means to convert the task of reading literature to be as a prescriptive task.

Furthermore, heads should come together to answer another strongly posed question :

- What kind of literature is in demand for teaching literature?

Putting the question another way :

- For teaching literature in an EFL tertiary level classroom, is it enough for the teachers of literature to be majored only in the field of literature or they should, in addition, be with certain distinguishing and unique intellectual aesthetic traits?

Answering such a question has absolutely to do with the cultivation of one's personal aesthetic and cultural disposition of both, learner and pedagogue.

Hence, if teaching literature is seen as more than the use of literary text in the English language classroom, one may then face the significance of the concept 'literary 
competence' of both, pedagogue and learner (Prumfit\& carter 2000 : p. 22; Shalan 2016).

Generally speaking, Widdowson argued that :

"...the term 'teacher' is traditionally used to refer to somebody with privileged access to wisdom : a sage or savant, whose teaching (or teachings) inspires reverence." (Widdowson 2003 : p.15)

Therefore, some other vital question to be posed :

- Has the literature teacher at the tertiary level EFLclassroom got such status described above in Widdowson's words, or they are always blamed of being persons coming with strange mandatorydemands which have only very little to do with the learners' goals to learn the English language?

Furthermore :

- If we come with guarantee that the assumed attribute in the term 'literature teacher' refers to someone who, in the EFL classroom, is 'privileged authority access to wisdom' plus 'aesthetic disposition to realize beauty values', shall such a teacher be definitely promising to meet the needs of learners who are linguistically proficient-enough and literary competent-enough, in order to make the status of literature 'caught' not 'taught' in the classroom?

As a matter of fact, teaching English literature, as part of any TEFL curriculum, has been one of the crucial teaching-learning complicated and sophisticated matters. This is, because of various factors related to both, pedagogues, who are assumed to be teachers plus aesthetes, and learners, who are in Widdowson's (3003 p.15) metaphorical terms, expected to be rustic-minded, because they in most of the cases might see the literary materials as convoluted ones imposed as a boring dutybound to be accomplished for the fulfillment of their EFL-learning.

Surprisingly, what a knotty situation could be found, when the teacher of literature has unexpectedly to deal, at an EFL tertiary classroom, with learners whose 'linguistic-proficiency' and 'literary competence' seems unpromising, in order to see through their readiness and disposition to read literature!

Then, a teacher like the one afore-honored by Widdowson's words, would s/he be able enough to cut the Gordian knot, i.e., be able to carry out two important tasks alongside each other; improving the learners' 'linguistic- proficiency' and developing their 'literary competence', and eventually fusing them in one task as a good deed of teaching literature?

As for teaching the English novel, in one's experience, in addition to the afore-mentioned ones, other difficulties might be found rearing their ugly heads for both teachers and learners. Hence, it would not be an easy task for the teacher of literature to address such EFL learners to enjoy reading a long literary text like a novel. Then, in order to turn the corner in favor of the above- mentioned double-faced task, what is to be done? Here, preferably, the teacher should at first find an approach to improve the learners' language skills, giving priority to the two skills reading and writing, in particular the first one. In his Reading Skills and the Study of Literature in Foreign Language, C. J. Brumfit argues that :

"...work in literature follows naturally from integrative activities in reading" (2000:187). Arguing for "Wider Reading for Better Reading", still speaking about teaching the novel, Brumfit puts the ball in the court of the teacher stating that:

"...one reason for our failure is that we do not actually ask students in school and colleges to read in the same way as we would expect to read ourselves" (Brumfit 2000 : 257). Finally, it seems that reading, in particular 'reading speed' (Pickett -ed. Brumfit \& Carter 2000 : 262) and writing which is defined by (ibid : 267) as "an ability to think and write clearly (as might be demonstrated in a variety of non-literary subjects)." The two skills, taken together, would establish preliminary stages to develop the learner's interest in how to enjoy reading the novel, which in its turn may guide them gradually to develop a personal advanced 'literary competence', and to eventually be followed by acquiring personal approaches to appreciate the literary aesthetic values of the novel they read.

\section{The Problem}

About the status of the novel in the Native English reader's culture, Richard Gill significantly stated that :

"The Harry Potter phenomenon tells us three things : We are still a nation of readers. We discuss what we read. Stories allure us"(Gill $2006: 3)$. The problem this study is to deal with is that the status of the novel to the EFL reader is not as it is to the Native English reader. This, in fact, put under suspension the tertiary level EFL learners' readiness to read literature, in particular long texts like novel text, and let alone their disposition to escape reading full literary texts, because they are still : 1.Having very poor repertoire of vocabulary. Duff and Maley (2003 : p.8) argues that "For many teachers the issue of vocabulary load is the main constituent of 'difficulty' in literary texts."

2. Developing only a low standard of 'literary competence', if none at all, in their native-language's literature, and. Getting used in previous levels of EFLL to spoon-feeding approaches of learning not to taskoriented and learner-oriented approaches ones, i.e., they hardly agree to carry out any task needed in the process of reading literature in the classroom. Harmer (2011 p.283) puts it another way saying :

"If they are struggling to understand every word, they can hardly be reading for pleasure". Finally, the problem is that how would a teacher of literature at the tertiary level has to address themselves to the task of 
teaching novel to EFL learners whose vocabulary repertoire is poor, their literary competence is also under question?

\section{Aims of the Study}

This study aims at:

A. Identifying the effectiveness of current approaches to teaching novel, at the tertiary level, in universities within Duhok Governorate area, and

B. Investigating the learners' reflections as feedbacks on the effectiveness of the said identified approaches.

\section{Limits of the Study}

The study is limited to :

A. Some current approaches to teaching novel to the college juniors and seniors in four English departments in the area of Duhok Governorate- Iraqi Kurdistan.

B. College juniors and seniors reflections on the assumed novel-teaching-approaches.

\section{Value of the Study}

The study importance might come from identifying the ways that attach significance to certain approaches used by some teachers of novel in the tertiary level languageclassroom to improve both, the learners' 'language proficiency' and 'literary competence' and to cast light on how to train the learners to enjoy reading full literary texts like the novel ones. Hence, the study could be a source of useful knowledge to both researchers and pedagogues.

\section{Hypotheses}

It is hypothesized that :

1.Technically speaking, teachers of novel do not have concrete knowledge about the literature-teaching approaches.

2. Teachers of novel have very little contact, if not at all, with any training on how to teach literature, or with reading any specialized relevant literature.

3. Teachers of novel have haphazard technicalknowledge about their students' needs in novelreading.

4. There are no significant differences between differentstudent-groups' reactions to the current novel-teaching approaches.

5. Teachers do not provide university EFL learners with pre-awareness of the novel-reading skill approaches.

\section{Definitions of Basic Terms}

1.Literary Awareness : It is the mental quality which depends on the activities which promote student's sensitivity the verbal aesthetic experience. (Zyngier 2007 : 195- cited in Shalan 2016)

2. Literary Education : It is the process of enhancement, whereby the noticing process allows additional information to enter the students' cognitive system and have the potential to develop their interpretive abilities (Hanaure 2007 : 170- cited in Shalan 2016)

3 .Literary Competence : The student's best ability to read and understand literary works and enjoy its aesthetic appeals. In terms of Psychology, Piclett, (-ed. 2000 : 278) call it 'literariness, and defined it as "mental objects communally possessed and liked together by some common essence... are of the same ontological status as the matter studied in the physical sciences" (cited in Shalan 2016).

3.Professionalism : In teaching, it is the status of teaching viewed in relation to its functions, to teachers' status, and to the quality and skill of their work. it also refers to an occupation that performs an important social function, based on a high degree of skill, not dependent upon routine behaviors, learned through education and training, and has its own principles and values (Richards \& Schmidt 2002 : 424-5).

\section{Related Literature}

It is widely acceptable nowadays in the educational research-work that the teaching of literature in the language-classroom has not got a fair share of concern in the evolution of the linguistic research fields. Such unfairness could be obviously explained by the words of Watson \& Zyngier, who plainly complained that:

"None of the theories of language learning directly states a role for literary reading within the language learning process" (Watson \& Zyngier 2007 : p.5). Meanwhile, in a compromising tone, Short, et al (ed2007 : p.106) argued that having a foot in the linguisticlanguage camp and the literature camp at the same time means to work harder to interest the learners, which eventually means to integrate language and literature. Furthermore, Zygier, Fiallo, and Prado Rios (2007 : p.197) argued for a need to build a progressive and sequential literary repertoire in the student's mind in order to help them response to new literary texts, and this cannot be achieved but by skillful merging, in the mind of the learners, between language and literature to be as one object. Accordingly, Duff \& Maley (2003), whose teaching of literature is most distinguished by their experience at overseas schools and universities, complained that :

"Literature, particularly in foreign language [teaching], is often seen as something remote and far removed from 'ordinary' language" (Duff \& Maley 2003 : 17). Hence, during the four recent decades the concern over this matter has increased among the researchers and educationists. Most of the discussions concentrated, and varied in view, on vital factors related to the role of literature in the EFL curricula. Some (almost majority) preferred the principle of language-based literature curriculum, i.e., reading the literary texts, in the language classroom, as a vehicle to enhance the 4language-skills' acquisition. Others (minority) argued for reading and teaching literature in the EFL classroom for its own right, in order to serve the learners' aesthetic taste education, by highlighting the literary texts' aesthetic and moral values. On the other hand, many 
questions on the nature of the role of literature in the language classroom went unanswered, although hot discussions took place on matters related to the teaching of literature in the EFL classroom, especially on the role of teaching literature in the progress of EFL learning. In this respect, a variety of speculations have been developed. Such speculations, in turn, developed applicable models of teaching literature in the EFL classroom especially with regard of enhancing both, the linguistic objectives and the aesthetic concerns. In this respect, among many important publications came during the two recent decades, the researcher would highly consider Brumfit \& Carter's (2000) Literature and Language Teaching, Duff \& Maley's (2003) Literature, Nozar \& Gautam's (2007) How to study Literature, Watson \& Zyngier's (2007) Literature and Stylistics for Language Learners, and the third edition of Lazar's (2013) Literature and Language Teaching. Some of the above-mentioned publications went even to discuss the minimum details of the teaching literature process in the EFL classroom, such as the lesson plan, objectives, and activities, in particular in Brumfit \& Carter (2000), Duff \& Maley (2003), and Lazar (2013). On matters related to teaching literature, in particular in the language classroom, Duff \& Maley (2003 : p.5) argued that the primary goal of any literature teachingapproach is to use literary texts as a source for stimulating language activities, by engaging the learners interactively with the text. They also argued to take the learner as an active agent not a passive recipient. As themselves (Duff \& Maley) teachers of literature, they encouraged the teachers of literature to bear in mind the following points as necessarilyemphasized ones :

- Let the activities offer ample opportunities for the learners to contribute and share their own experience, - Allow the literary text to suggest the type of activity, whether in the classroom or at home,

- Let the literary text to be presented in a variety of ways,

- Do not let the text to be the only element in the learning activity, i.e., let it be one key-element in a linked set of activities, and

- Do not take the literary-quality as the only criterion for selecting the literary texts (Duff \& Maley 2003 : p.6). Hence, Duff \& Maley (2003 : p.6) argued that there are three types of reason for using literary text in the language classroom : linguistic, methodological, and motivational. They also believe that "if the [literary] text is difficult it should not be chosen..." (ibid : p. 8), and for this reason they believed that "the literature of our time is more accessible for foreign learners" (ibid : p.8). Finally, speculating their approach of teaching literature, Duff \& Maley (2003 : p.9) emphasized the nature of their approach as one which is : -not characterized as a study of literature, -using literary texts for language learning, -not casting sacredness on literary texts, and -being helpful for those learners who eventually wish to study literature.

On the other hand, few years before Duff \& Maley (2003), Brumfit \& Carter (2000) speculated the EFL literature syllabus as one which should have two broad stages :

-the first is concerned with enabling the learners to 'experience' literature, and

-the second is devoted to enabling them to describe, explain, or 'account for' the above-said experience (ibid. p.31). But, in their opinion, the error of much of literature teaching is that the practice of the process is reserved (ibid. p.31). But, furthermore, they argued that the second stage afore-mentioned, could be an option for those who tend to be self-conscious about the process of reading literary texts, which implicitly indicates developing their 'literary awareness'. It is for this reason, they argued that the development in 'literary awareness' entails "development of awareness of varieties of English in use..." which is "...crucial to an adequate teaching of literature in a foreign language..." and that "...literature study should also enhance awareness of language functions" (ibid. p : 38). And finally agreeing with arguments about starting teaching literature from the language activities in the classroom to enter the realm of literature (ibid. $\mathrm{p}: 38$ ). However, in respect of teaching literature, a warning came from Short \& Candlin (ed-2000 : pp. 90-1) claiming that nonnative teachers of English or specialist language teachers [of literature] frequently retreated into teaching about literature, not literature itself, by giving the learner only :

"...biographical facts about authors, description of literary movements and critical schools, synopses of novels and plays" (ibid., : 90),

Thus, they added :

"...literature teaching began to disappear from the 'language classroom, to be replaced by surrogate literature" (ibid. : 91). A similar point of view came from Carter (ed- 2000 : 110), who put it in other words, saying that the use of linguistic models would make it possible to work on what he technically called it 'literariness' of texts rather than on texts as literature, considering 'literariness' as one of the most essential components that develops the learners' 'literary competence'. Very outstanding views about the teaching of literature in the EFL classroom came from Michael N. Long (ed- 2000 : 41-59), who concentrated on the literature's teachingprocess. He argued that the teaching of literature could be an 'arid business' without getting response from the learner, especially when the teacher of literature is not imaginative enough or pedagogically uncreative to get 
'response' from the learners, because even negative responses can create an interesting classroom situation (ibid, p. 42-3). He also argued that for non-native learners the approach of teaching should necessarily be so different that any 'response' means basically "classroom interaction between pedagogue and learner" (ibid, p. 43). Furthermore, he put emphasis on the differentiation between teaching literature to the native-speakers and the non-native speakers, arguing that it should be so because with the former many loworder demands would be out of the question, while with the non-native learner the afore-mentioned loworder demands are a "natural enough step, because the student should come to expect that a higher-order question will follow." (ibid. : 45). Then, among the explanation of so many vital elements of the teaching process, Long's essential achievement is the diagram he created for a multi-directional cognitive process of teaching-learning which goes between two poles, teachers and learners. Here below Michael Long's diagram :

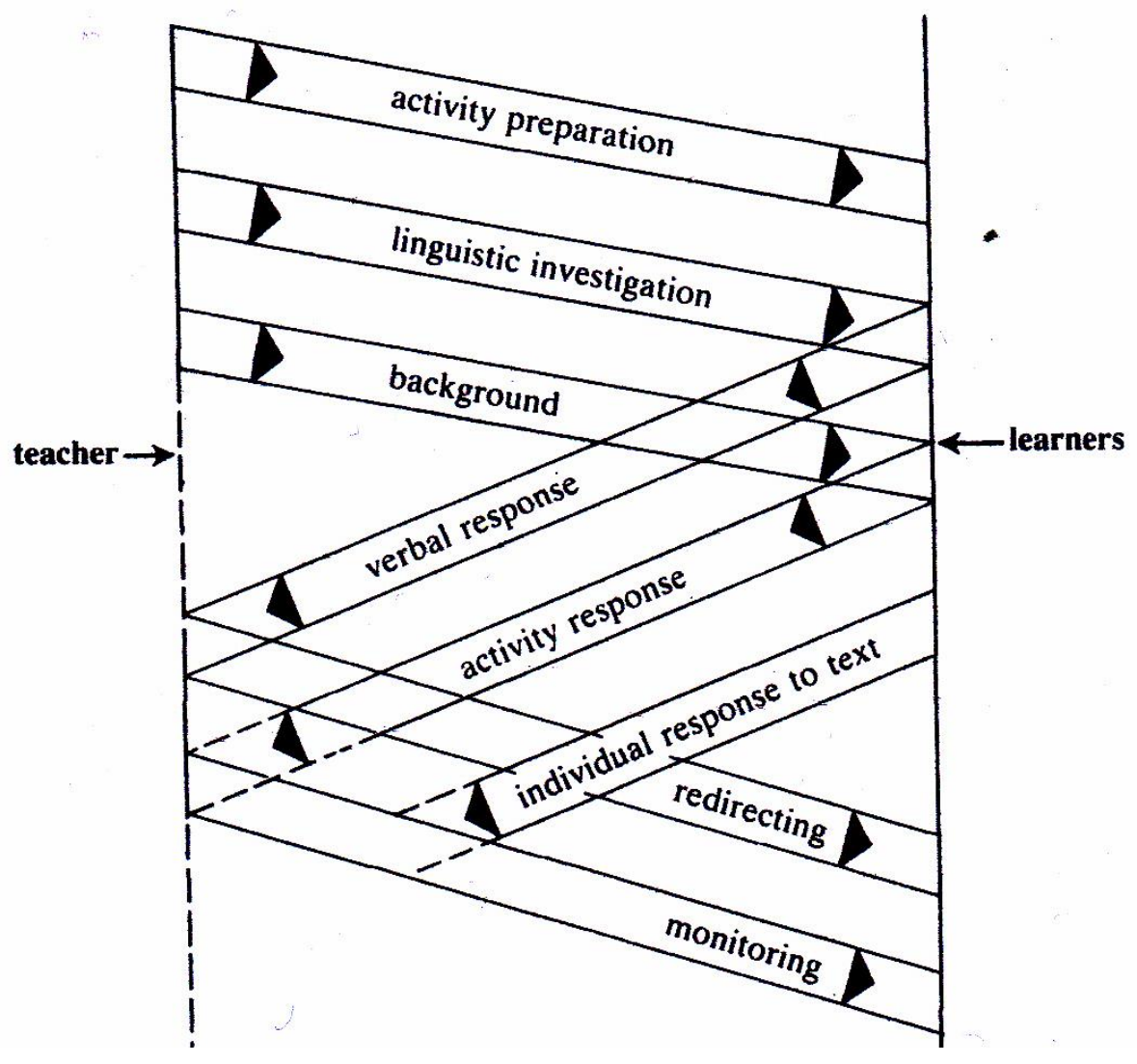

Figure 1 : Michael Long's multi-directional diagram

Long explained his diagram saying that :

"...it presupposes the availability of suitable [literary] textbooks, among other things... it does seem that it opens up a necessary 'varied approach' to the teaching of literature" (ibid. : 54). Finally, a prominent attempt came from Lzar (2013) to suggest a set of approaches to using literature with language learners. She argued that pinpointing possible approaches would help the teacher of literature to select and design materials for classroom. The merit of Lazar's work is that, in his Literature and Language Teaching (2013), which is completely devoted for teaching literature in practice, she put an overview of overall aims and methodological assumption for the speculation of a model with three presumed alternative approaches to teaching literature. Here below is a summarization of Lazar's tri-assumedalternative approaches model :

1- A language-based approach

a. METHODOLOGICAL ASSUMPTIONS : Studying the language of the literary text would help to integrate the language and literature syllabuses more closely, for this could help the learners to make meaning interpretations and evaluations of it, as well as increasing their general literary awareness and to make aesthetic judgments of the text. 


\section{b. SELECTION AND ORGANIZATION OF} MATERIAL : Materials are chosen for the way they illustrate certain stylistic features of the language but also for its literary merit.

2 - Literature as content

a. METHODOLOGICAL ASSUMPTIONS : This is a traditional approach, which has been frequently used in tertiary-level education, where literature itself is the content of the course, concentrating on areas such as the history and characteristics of the literary movements, the social, political and historical background to a text, as well as literary genres and rhetorical devices. Learners acquire English by focusing on course content, by reading set texts and literary criticism. The learners' mother tongue can be used to discuss the text.

\section{b. SELECTION AND ORGANIZATION OF}

MATERIAL : Text are selected for their importance as part of literary canon or tradition

\section{Literature for personal enrichment}

a. METHODOLOGICAL ASSUMPTIONS : Literature is a useful tool for encouraging students to draw on their own experiences, feeling and opinions. It helps students to become more actively involved both intellectually and emotionally in learning English, and hence aids acquisition, and as an excellent stimulus for group work.

\section{b. SELECTION AND ORGANIZATION OF} MATERIAL : Material is chosen on the basis of whether it is appropriate to students' interests and will stimulate a high level of personal involvement. Material is often organized thematically, and may be place alongside non-literary materials which deal with a similar theme" (Lzar 2013 : 22-3-4). Obviously, the language-based approach is a syllabus-based one, which can cover a range of different goals and procedures, while the literature as content approach is teacher-oriented one, and in terms of the teachers of literature, can be considered as the province of the literature teacher rather than the language teacher, and only to be used with learners who are assumed to be proficient in their 'literary competence', whereas the literature for personal enrichment approach is a learner-oriented one, which encourages the learners to explore literature themselves as (ibid. : 27,35,39).

\section{Procedures}

\subsection{The Study Population \& Sample}

EFL teachers \& learners at 4 departments of English were chosen as study-population. Then, as studysample of 6 teachers of novel and 6 groups (each 10) of students were chosen from the following sources :

1.Group 1 : 10 juniors /Col. of Arts (CoAs)/ Uni. of Duhok (UoD)
2.Group 2 : 10 seniors /Col. of Arts (CoAs)/ Uni. of Duhok (UoD)

3.Group 3 : 10 juniors /Col. of Basic Education (CoBE)/ Uni. of Duhok (UoD)

4.Group 4: 10 juniors /Faculty of Languages (FoL)/

Uni. of Zakho (UoZ)

5.Group 5 : 10 seniors /Faculty of Languages (FoL)/ Uni. of Zakho (UoZ)

6. Group $6: 10$ juniors of Col. of Languages (CoL)/ Nawroz Uni. (NzU)

Then, in addition to the 6 groups of students, the 6 relevant teachers of novel, from the said 4 departments of English, were chosen as a study-sample.

\subsection{Interviews and Questionnaire Design}

A. Using Lazar's tri-assumed-approach-model as a reference, an interview form (see App. 2-a) was designed and distributed to 6 novel-teachers to investigate the effectiveness \& professionalism of their approaches to teaching novel. In addition to that a questionnaire form was designed with 6-statement-item (see App. 2-b) to investigate how far the said teachers had concern with training on how to teach literature, in particular novel.

B. An interview form (see App. 3-a) with 60 students was designed, (Lazar's tri-assumed-approach-model used as a reference- see section 7 above), to identify how far their expectations about the novel-teaching approach would match with the one specified by their teachers. In addition to that a questionnaire form of 17statement-items (see App. 3-b) was designed to investigate the effectiveness of the said approaches to teaching novel and the students' interaction with them. Naturally, both the teachers and the students' questionnaire versions validity and reliability were examined by a jury (see App. 1). The questionnaires statement-items were given the options : always, often, sometime, rarely, and never. A scoring-scale of (4-0) was given to positive statement-items, and was converted into (0-4) for negative statement-items.

\subsection{Data Analysis and Discussion.}

\subsubsection{Teachers Feedback}

\subsubsection{Interview}

(Table No. 1) below shows the feedback of 6 novel teachers, (4 males \& 2 females), with an experiencerange of (1-10 years) in teaching novel.

3. For $Q 1$, each of them identified one of Lazar's triassumed-model approaches as matching with her/his approach of teaching.

4.For Q 2, their replies came as follows : "Never heard or read about it.", "Never heard or read.", "Absolutely, no.", "No.", "Unfortunately, I have not!", "Somewhat and somehow." 
Table No. (1) : Responses of 6 novel-teachers Interviewher

\begin{tabular}{|c|c|c|}
\hline No. & Indicators & Details \\
\hline \multirow{4}{*}{1} & Ref. & UoD/CoAs/ $3^{\text {rd }}$-year \\
\hline & Nov.(s) & Forty Rules of Love by Elif Shafaq \\
\hline & Answers & $\begin{array}{l}\text { Q 1: I have tried to get my students involved in both 'Critical } \\
\text { Reasoning' and 'language acquisition'. In this way I think we can } \\
\text { focus on the literary and stylistic aspects. As we know it is very } \\
\text { similar to the first approach 'language-based approach' } \\
\text { Q 2: Never heard or read about it. }\end{array}$ \\
\hline & Fur. Comm. & $\begin{array}{l}\text { In our department, we already have tried to update our teaching } \\
\text { methods, but as for the other colleges, I think they are following the } \\
\text { very classical approaches that we mentioned here. So, if you } \\
\text { conduct your researches in some other English departments it will } \\
\text { give it more credibility. }\end{array}$ \\
\hline \multirow{4}{*}{2} & Ref. & UoD/CoAs/ $4^{\text {th-stage }}$ \\
\hline & Nov. & $\begin{array}{c}\text { Sons and Lovers by D.H. Lawrence \& The Color Purple by Alice } \\
\text { Walker }\end{array}$ \\
\hline & Answers & $\begin{array}{l}\text { Q 1: I believe the third approach 'Literature for personal } \\
\text { Enrichment' may be most needed, since the more emotional } \\
\text { involvement into the novel, the more connection the students can } \\
\text { make that will result in more acquisition of the topic. } \\
\text { Q 2: Never heard or read. }\end{array}$ \\
\hline & Fur. Comm. & Nil \\
\hline \multirow{4}{*}{3} & Ref. & UoD/CoBE/3rd_stage \\
\hline & Nov.(s) & $\begin{array}{c}\text { Beloved by Toni Morrison \& The Scarlet Letter by Nathaniel } \\
\text { Hawthorne }\end{array}$ \\
\hline & Answers & $\begin{array}{l}\text { Q 1: The first approach is important, since we teach literature to } \\
\text { make the students master the English language. The second } \\
\text { approach 'Literature as content' cannot be denied as literature is } \\
\text { connected to its historical background. } \\
\text { Q 2: Absolutely, no }\end{array}$ \\
\hline & Fur. Comm. & Nil \\
\hline \multirow{4}{*}{4} & Ref. & UoZ/FoL/ $3^{\text {rd-stage }}$ \\
\hline & Nov.(s) & Wuthering Heights by Emily Bronte \\
\hline & Answers & $\begin{array}{l}\text { Q 1: As a teacher of novel, I believe that the third approach } \\
\text { 'Literature for personal enrichment' is suitable one as far as } \\
\text { students are concerned. Obviously, this method helps the students } \\
\text { to improve their skills as learners on different levels, language } \\
\text { learning and appreciation of literature, for readers not teachers. } \\
\text { Q 2: No. }\end{array}$ \\
\hline & Fur. Comm. & Nil \\
\hline \multirow[b]{3}{*}{5} & Ref. & UoZ/FoL/ $4^{\text {th }}$-stage \\
\hline & Nov.(s) & $\begin{array}{l}\text { Lord of the Flies by William Goldings \& Democracy by Toan Didion } \\
\text { \& The Old Man and the Sea By Ernest Hemingway \& Manuscript } \\
\text { Found in Accra by Coelho }\end{array}$ \\
\hline & Answers & $\begin{array}{c}\text { Q 1 : I believe it depends on students' pre-readiness for and pre- } \\
\text { knowledge regarding novel. The second approach (Literature as } \\
\text { Content) is the most appropriate one in teaching novel to students } \\
\text { who have not studied novel previously (as it is the case with second } \\
\text { year students or third year). }\end{array}$ \\
\hline
\end{tabular}




\begin{tabular}{|c|c|c|}
\hline & & Q 2 : Unfortunately, I have not! \\
\hline & Fur. Comm. & $\begin{array}{l}\text { In order to select the right teaching approach content, I usually do a } \\
\text { pre-test at the beginning of the academic year. The result of this test } \\
\text { helps me in designing my course books. }\end{array}$ \\
\hline \multirow{4}{*}{6} & Ref. & $\mathrm{NzU} / \mathrm{CoL} / 3^{\text {rd }}$ stage \\
\hline & Nov.(s) & The Scarlet Letter by Nathaniel Hawthorne \\
\hline & Answers & $\begin{array}{l}\text { Q 1: Each of the approaches has its good and bad effects. I think the } \\
\text { third one "Literature for Personal Interest" suits the needs of the } \\
\text { students the best, because it serves them to be independent learners } \\
\text { and fosters self-autonomy and confidence in the students. } \\
\text { Q } 2 \text { : Somewhat and somehow. }\end{array}$ \\
\hline & Fur. Comm. & $\begin{array}{l}\text { Generally, reading literature enhances students' skills of learning. } \\
\text { Novel aims to make its reader enjoy the language plus its content. } \\
\text { Students need to consider how to build the personal skills and } \\
\text { enrich their language in addition to critical thinking of the elements } \\
\text { and figures of the story. The third approach is highly interesting for } \\
\text { students, and the second one serves them well as well. }\end{array}$ \\
\hline
\end{tabular}

\subsubsection{Questionnaire}

In order to identify the effect of training on the novel teacher's achievement in teaching his students, the researcher used the ANOVA statistical model (see Table No. 2 below) to make comparison between the teachers' choices of the novel-teaching-approach and its effect on the students' interaction. The results brought no significant differences (.694) in this respect.

Table (2) : Novel Teachers feedback about training

\begin{tabular}{|c|c|c|c|c|c|}
\hline & $\begin{array}{c}\text { Sum of } \\
\text { Squares }\end{array}$ & df & Mean Square & F & Sig. \\
\hline Between Groups & 15.000 & 2 & 7.500 & .413 & .694 \\
\hline Within Groups & 54.500 & 3 & 18.167 & & \\
\hline Total & 69.500 & 5 & & & \\
\hline
\end{tabular}

\section{9-3-2 Students Feedback}

\section{9-3-2-1 interview}

(Table No. 3) below shows results of the students' feedback answering the student-interview's 2 questions.

1. For question 1 : "Have you been ever enlightened by your teacher as to the nature of novelreading?"

The results came passive with 'No' as follows : 9, 8, 10, $10,8,8$ out of 10
2. For question 2: "Which one of the following novel-teaching approaches do you think would match most with the novel-teaching approach your teacher has been following?"

The results showed no significant majority of agreement among any of the student's 6 groups expectations of the teacher's approach to teaching novel.

Table (3) : Results of the students' interview.

\begin{tabular}{|c|c|c|c|c|c|c|c|}
\hline & Answer & Group 1 & Group 2 & Group 3 & Group 4 & Group 5 & Group 6 \\
\hline \multirow{2}{*}{$\begin{array}{c}\text { Question } \\
1 \\
\end{array}$} & Yes & 1 & 2 & 0 & 0 & 2 & 2 \\
\hline & No. & 9 & 8 & 10 & 10 & 8 & 8 \\
\hline \multirow{2}{*}{$\begin{array}{c}\text { Question } \\
2\end{array}$} & Appro.1 & 3 & 2 & 1 & 3 & 2 & 2 \\
\hline & Appro. 2 & 5 & 4 & 5 & 4 & 4 & 3 \\
\hline
\end{tabular}




\begin{tabular}{|l|l|l|l|l|l|l|l|}
\hline & Appro.3 & 2 & 4 & 4 & 3 & 4 & 5 \\
\hline
\end{tabular}

(Table No.4) below shows the students' expectations about the novel-teaching approach compared to the one specified by their teacher.
The students' answers about their expectations of the teaching approach type used by their teacher as follows $: 3,4,5,3,4,5$ out of 10 .

Table (4) : Comparison between the Teachers' specifications and students' expectations about the novel teaching approach

\begin{tabular}{|c|c|c|c|c|c|c|}
\hline $\begin{array}{c}\text { Method } \\
\text { chosen by } \\
\text { teacher }\end{array}$ & Group 1 & Group 2 & Group 3 & Group 4 & Group 5 & Group 6 \\
\cline { 2 - 7 } & \multicolumn{6}{|c|}{ Teacher's teaching approach matching to one of Lazar Model's approaches } \\
\hline Approach. 1 & $*$ & & & & & \\
\hline Approach. 2 & & & $*$ & & $*$ & \\
\hline Approach. 3 & & $*$ & & $*$ & & $*$ \\
\hline Students' guesing their teacher's approach of teaching with reference to Lazar's Model \\
\hline Approach. 1 & 3 & 2 & 1 & 3 & 2 & 2 \\
\hline Approach. 2 & 5 & 4 & 5 & 4 & 4 & 3 \\
\hline Approach. 3 & 2 & 4 & 4 & 3 & 4 & 5 \\
\hline
\end{tabular}

\subsubsection{Questionnaire Feedback}

Below, the findings were reached about the students' interaction with the novel-teaching approach followed by their teacher.
1. According to the stage variance, a t-test statistical hypothesis (see Table No. 5 below) with two independent samples was used. The results brought no significant (.791) differences between the $3^{\text {rd }}$-stage and $4^{\text {th }}$-stage students' interaction with the novel-teachingapproaches.

Table (5) : Results showing the students' feedback according to study-stage

\begin{tabular}{|c|c|c|c|c|c|c|c|}
\hline & Class & $\mathrm{N}$ & Mean & $\begin{array}{c}\text { Std. } \\
\text { Deviation }\end{array}$ & $\begin{array}{c}\text { Std. Error } \\
\text { Mean }\end{array}$ & $\mathrm{t}$ & \multirow{2}{*}{ Sig. } \\
\hline \multirow{2}{*}{ Total } & 3.00 & 40 & 42.4750 & 7.17898 & 1.13510 & \multirow{2}{*}{267} & \multirow{2}{*}{.791} \\
\cline { 2 - 6 } & 4.00 & 20 & 43.0000 & 7.21110 & 1.61245 & & \\
\hline
\end{tabular}

2. For the college variance, the same NOVA model (see Table No. 6 below) results brought no significant (.063)) differences.

Table (6) : The Students' feedback according to college variance

\begin{tabular}{|c|c|c|c|c|c|}
\hline & Sum of Squares & df & Mean Square & F & Sig. \\
\hline Between Groups & 363.300 & 3 & 121.100 & 2.570 & .063 \\
\hline Within Groups & 2638.350 & 56 & 47.113 & & \\
\hline Total & 3001.650 & 59 & & & \\
\hline
\end{tabular}

3. The ANOVA model (see Table No. 7 below) brought no significant (.074) differences according to the university variance. 
Table (7) : Students' feedback results according to universities

\begin{tabular}{|c|c|c|c|c|c|}
\hline & Sum of Squares & df & Mean Square & F & Sig. \\
\hline Between Groups & 261.900 & 2 & 130.950 & 2.724 & .074 \\
\hline Within Groups & 2739.750 & 57 & 48.066 & & \\
\hline Total & 3001.650 & 59 & & & \\
\hline
\end{tabular}

4. The ANOVA model (see Table No. 8 below) results brought no significant (0266) differences between the students opinions attributed to any of the novel-teachingapproaches used by the 6 novel teachers.

Table (8) : Students (reconsidering the students' opinions about the approach in particular : which approach do you think your novel teacher is using?)

\begin{tabular}{|c|c|c|c|c|c|}
\hline & Sum of Squares & df & Mean Square & F & Sig. \\
\hline Between Groups & 136.283 & 2 & 68.142 & 1.356 & .266 \\
\hline Within Groups & 2865.367 & 57 & 50.270 & & \\
\hline Total & 3001.650 & 59 & & & \\
\hline
\end{tabular}

\section{Conclusions and recommendations} 10.1 Conclusions

To conclude, the findings in general proved most, if not all, of the hypotheses made by this paper as follows :

1. No teacher of novel involved in the study-sample has approved concrete knowledge about the literatureteaching approaches, in particular teaching novel. As such, hypothesis No.1 has been accepted and proved.

2. Teachers of novel have very little contact with the training-programs of how to teach literature. As such, hypothesis No. 2 has been accepted and proved.

3 . Teachers of novel have haphazard technicalknowledge about their students' needs in novelreading. As such, hypothesis No. 3 has been accepted and proved.

4. No significant differences were found between different-student-groups' interactions with the approaches to teaching novel followed by their teachers. As such, hypothesis No. 4 has also been accepted.

5. Teachers do not provide university EFL learners with pre-awareness of the key novel-reading skills. As such, hypothesis No.5 has been also proved and accepted.

In addition to the findings which are related directly to the hypotheses, the following ones could be justified :

6.3 of the investigated teachers match their teaching approach to the $3^{\text {rd }}$ approach of Lazar's model 'Literature for Personal Enrichment', which indicated a kind of tilting towards a student-centered approach in teaching. Meantime, 2 teachers preferred the $2^{\text {nd }}$ approach in Lazar's Model 'Literature as content', which indicated that the teacher adopted a mixture of student-centered and teacher-centered approach, whereas only one teacher preferred the $1^{\text {st }}$ approach in
Lazar's Model 'Language-based', which is almost a teacher-based one.

7. Only minority of the study-sample-students could make rough conception about the theoretical frame of their teacher's approach to teaching novel.

8. A well-qualified teacher in literature does not mean he would be a good teacher of literature unless they have enough awareness of how to teach literature, novel in particular.

9. Not few of the students' feedbacks indicate that in most of the cases they did not read novel, they rather read about novel not the novel itself.

10. Most of the students, if not most of their teachers as well, lack the skill of speed reading, which is a necessary prerequisite for reading a lengthy literary text in the language classroom.

\subsection{Recommendations}

It was recommended that :

1. It is very necessary for both, learner and teacher of literature to be trained on rapid reading.

2. Teachers of literature should be qualified in the methods of teaching literature as part of their qualification in literature, because such qualification and training would help them much to guide their students to experience the worlds of true literature realm.

\section{References}

1. Abrams, M. H. \& Harpham, Geophrey Galt (2009) A GLOSSARY OF LITERARY TERMS. WADSWORTH CENGAGE Learning. Australia, Brazil, etc.

2. Alexander, L. G. (1971) Poetry and Prose Appreciation : For Overseas Students. Lngman. London 
3. Alsagorff, Lubna \& McKay, Sandra Lee \& $\mathrm{Hu}$, Gwangwei \& Renadya, Willy A. (2012) Principles and Practices for Teaching English as a Global Language. Routledge. UK \& USA

4. Brumfit, C. J. \& Carter R. A. (2000) Literature and Language Teaching. Oxford University Press Hong Kong

5.Carter, R. A. (1999) Literature Reading. In Spolsky, Bernard (199) CONCISE ENCYCLOPEDIA OF EDUCATIONAL LINGUISTICS. Oxford UK

6. Chambers, Ellie \& Gregory, Marshal (2006) Teaching and Learning English Literature. Sage Publications. London \& New Delhi

7. Cook, Vivian (2008) Second Language Learning. HODDER EDUCATION. UK

8. Cudden, J. A. revised by Preston, C. E. (1998)

Dictionary of LITERARY TERMS \& LITERARY THEORY. PINGUIN REFERENCE. London. UK

9. Duff, Aian \& Maley Alan (2003) Literature. Oxford University Press New York

10. Gill, Richard (2006) MASTERING ENGLISH LITERATURE. PALGRAVE MASTER SERIES. Macmillan. New York

11. Grifith, Peter (1984) Literary Theory and English Teaching. Open University Press. England

12. Harmer, Jeremy (2011). The Practice of English Language Teaching. Pearson \& Longman. England 13. Hedge, Tricia (2003) Teaching and Learning in the Language Classroom. Oxford University Press. China
14. Lazar, Gillian (2013) Literature and Language Teaching. Cambridge University Press. UK

15. Madden, Frank (2004) EXPLORING LITERATURE. Pearson \& Longman. New York

16. Richards, Jack C. \& Farrell, Thomas S. (2012) PROFESSIONAL DEVELOPMENT FOR LANGUAGE TEACHERS : Strategies for Teacher Learning. Cambridge University Press. USA

17. Scrivener, Jim (2011) Learning Teaching : The Essential Guide to English Language Teaching. Macmillan Books. UK

18. Senior, Rose M. (2006) The Experience of Teaching English. CAMBRIDGE UNIVERSITY PRESS. UK

19. Watson, Greg \& Zyngier, Sonia (2007) -ed. Literature and Stylistics for Language Learners. Palgrave Macmillan. UK

20. Widdowson, H. G. (2003) Defining Issues in English Language Teaching. Oxford. New York

App. 1 : Jury Names :

1. Dr. Hussein Ali Gargari (Prof.)/ College of Languages/ Nawroz University

2. Dr. Chachaan Jum'ah Mohammed (Assist. Prof.)/Department of Psychological \& Educational Sciences /Faculty of Basic Education/University of Duhok

3. Dr. Sami Abdul-Aziz Al-Ma'mouri (Prof.)/Department of English/College of Basic Education/ University of Diyala.

App. 2.a :

Teachers' Interview

Interview

Dear Madam/Sir

The researcher is carrying out a study: 'The Effectiveness of current approaches to teaching

Novel to University EFL Learners : Investigation \& Reflections'

And he has taken a tri-alternative-approach-model to teaching literature suggested by Gillian Lazar (2013) as a reference-model for teaching literature.

As a result of competence you have in this field, after reading Lazar's reference-model below, would you please give your frank and sincere response to the questions which follow:

Expecting your cooperation, please accept my best regards.

The researcher

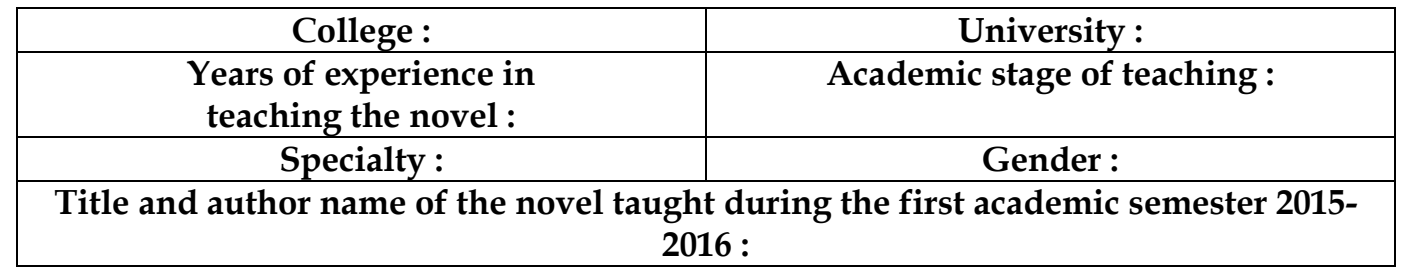

\section{Reference-model for Teaching Literature}

The merit of Gillian Lazar's work is that, in his Literature and Language Teaching (2013), which is completely devoted for teaching literature in practice, he put an 
overview of overall aims and methodological assumption for the speculation of a model of tri-alternative-approaches assumed to teaching literature. Here below the three assumed approaches :

....Facsimile of Lazar's tri-assumed-approach model ....

(see sec. 7 Related Literature)

Obviously, the language-based approach can cover a range of different goals and procedures, and the literature as content approach is, in terms of the teachers of literature, the province of the literature's teacher rather than the language's teacher, and only used with learners who are assumed to be proficient in their 'literary competence', while the literature for personal enrichment approach the one which encourages the learners to explore literature themselves. (ibid., pp. 27,35,39).

\section{Interview}

Q 1: As a teacher of English literature, the novel in particular, and you have never been aware of Lazar's presumed approaches of teaching literature, which one of them, you believe, may approximate yours in practice in order to meet mostly the needs of teaching the novel? A :

Q 2 : Have you ever heard about or read about the above-mentioned Lazar's triassumed-model of teaching literature or any other model of teaching literature?

\section{Any Further Comment :}

Note : Please, use the back of the form-sheet to write the responses.

App. 2.b

Teachers' Questionnaire

\begin{tabular}{|c|c|l|l|l|l|l|}
\hline No. & \begin{tabular}{c} 
Statement-items \\
\hline 1
\end{tabular} $\begin{array}{c}\text { My approach of } \\
\text { teaching the novel } \\
\text { always went smooth }\end{array}$ & Olways & Often & Sometimes & Rarely & Never \\
\hline 2 & $\begin{array}{c}\text { My students } \\
\text { interaction with my } \\
\text { approach of teaching } \\
\text { the novel was } \\
\text { unsatisfactory }\end{array}$ & $\begin{array}{c}\text { I am used to join } \\
\text { training course in } \\
\text { teaching literature } \\
\text { educational literature } \\
\text { of how to teach } \\
\text { literature }\end{array}$ & & & & \\
\hline 4 & $\begin{array}{c}\text { I never read } \\
\text { I tilt to choose simple } \\
\text { novel full-text but not } \\
\text { simplified! }\end{array}$ & & & & & \\
\hline 6 & $\begin{array}{c}\text { I was aware enough } \\
\text { of the methods of } \\
\text { teaching the novel in } \\
\text { advance }\end{array}$ & & & & & \\
\hline
\end{tabular}




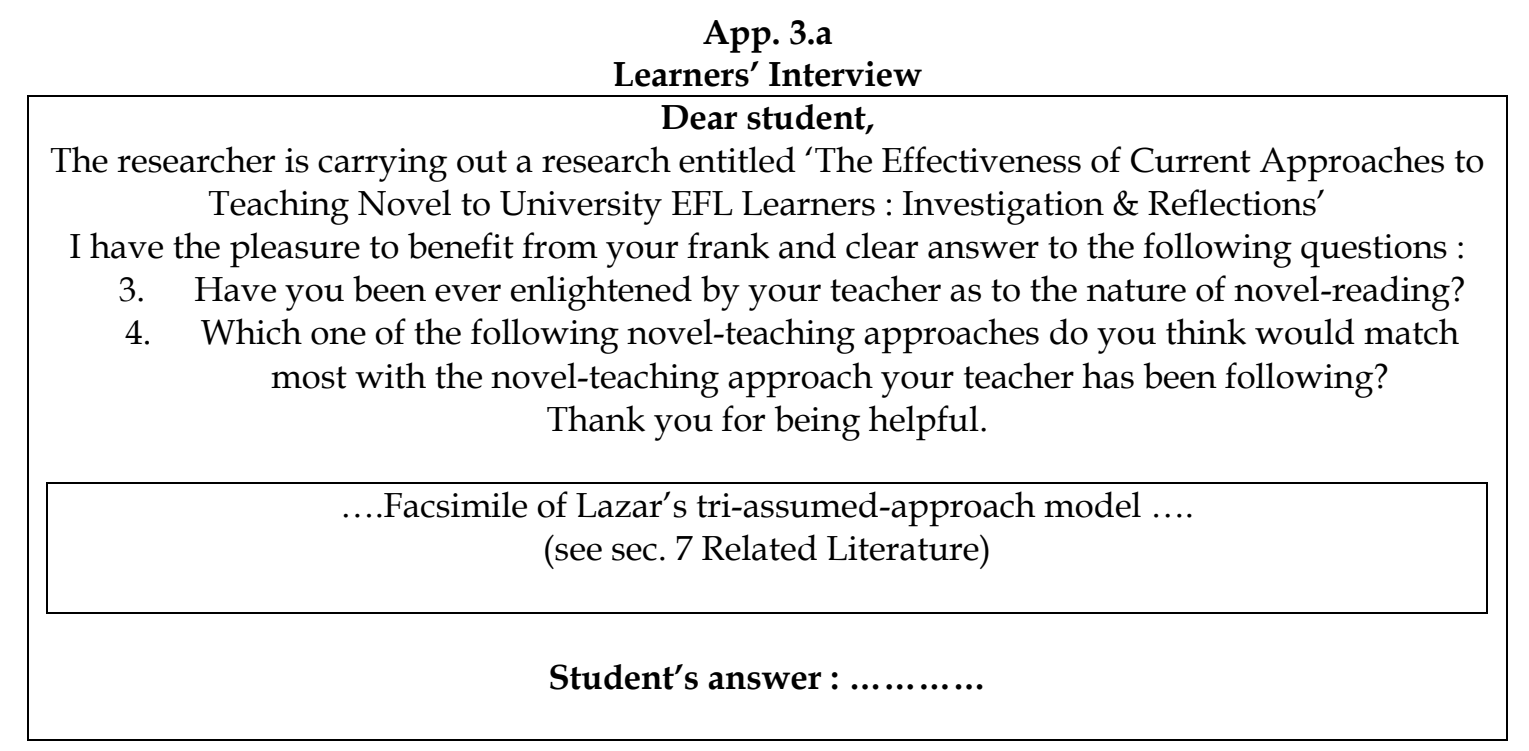

App. 3-b : Learners' questionnaire

\section{Questionnaire}

Dear Student'

The researcher is carrying out a research entitled 'The Effectiveness of Novel Teaching

Approaches at University : Investigation \& Reflections'

I have the pleasure to benefit from your frank and clear answers to the following questionnaire statement-items.

Thank you for being helpful.

Important Note : When ticking in the boxes against the statement-items below, bear in mind that you are giving feedback about the English-Novel-Teaching-Method (ENTM henceforth) adopted by your teacher in your classroom for this year.

The Researcher

\begin{tabular}{|c|c|}
\hline University : & College : \\
\hline Department : & Stage : \\
\hline Age : & Gender : \\
\hline
\end{tabular}

\begin{tabular}{|c|c|l|l|l|l|l|}
\hline No. & Items & Always & Often & $\begin{array}{c}\text { Some- } \\
\text { times }\end{array}$ & Rarely & Never \\
\hline 1 & $\begin{array}{c}\text { ENTM helps me to follow-up } \\
\text { what takes place in the novel. }\end{array}$ & & & & & \\
\hline 2 & $\begin{array}{c}\text { ENTM does not help me to } \\
\text { know why the characters are } \\
\text { behaving in the way they do. }\end{array}$ & $\begin{array}{c}\text { ENTM stimulates me to be } \\
\text { aware of the change in the } \\
\text { characters' mood through the } \\
\text { novel's episodes. }\end{array}$ & & & & \\
\hline 4 & $\begin{array}{c}\text { ENTM enables me to see how } \\
\text { the plot is moving. }\end{array}$ & & & & & \\
\hline 5 & $\begin{array}{c}\text { ENTM does not enable me to } \\
\text { identify the features of the } \\
\text { novel I am reading are } \\
\text { different from other novels. }\end{array}$ & & & & & \\
\hline 6 & $\begin{array}{c}\text { ENTM enables me to } \\
\text { visualize the events }\end{array}$ & & & & & \\
\hline
\end{tabular}




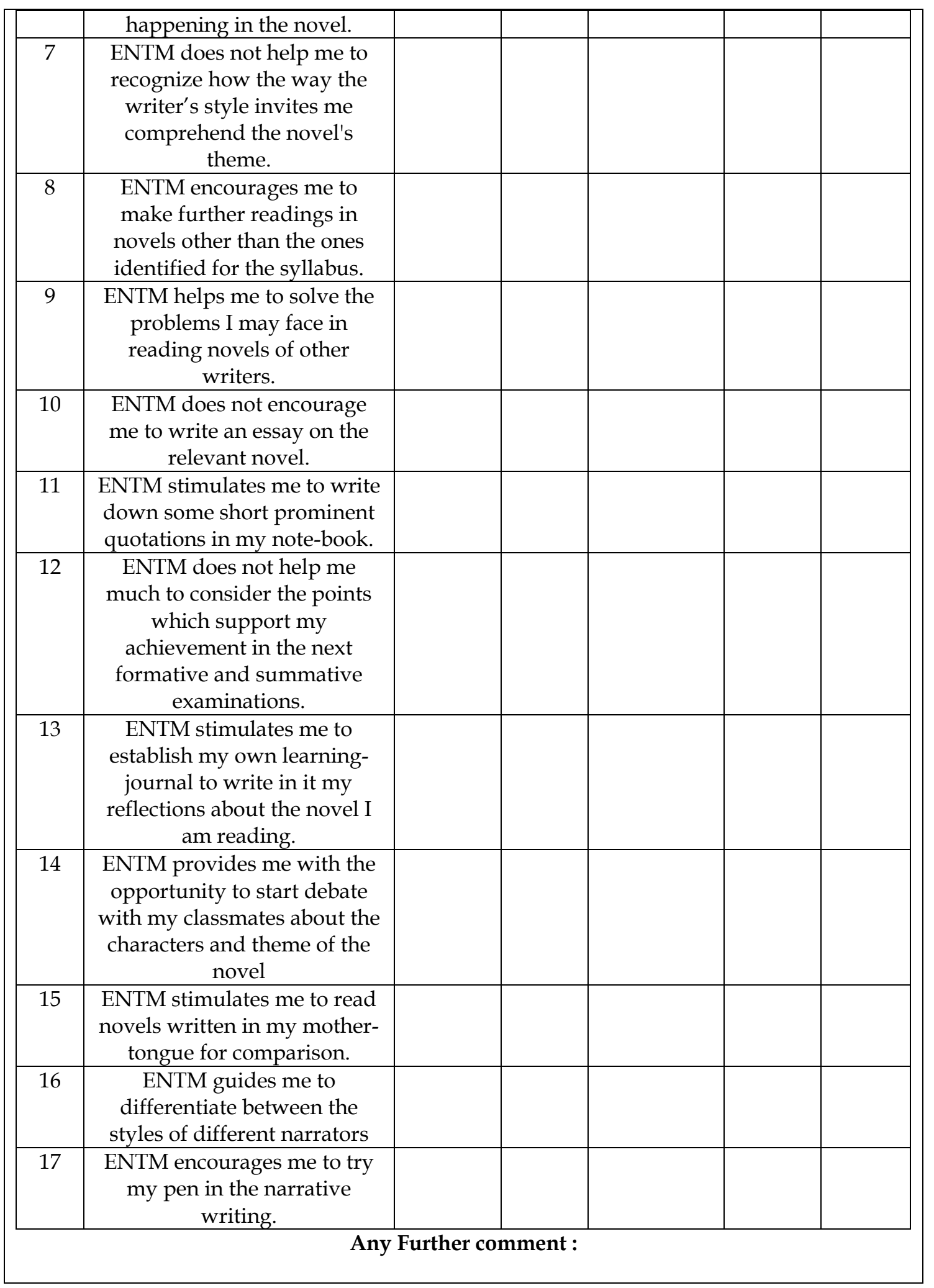

